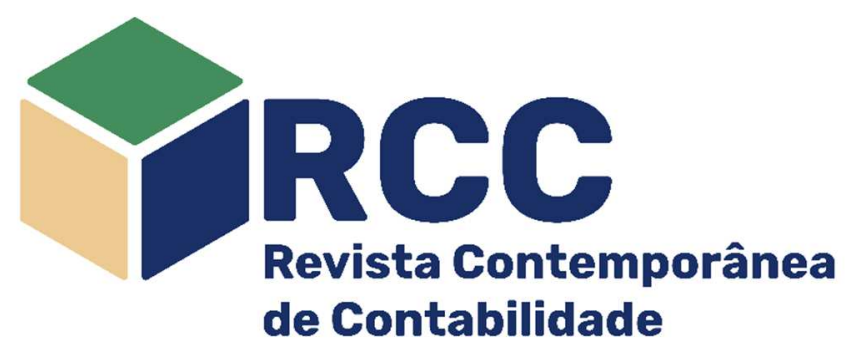

\title{
An analysis of the content and quality of corporate sustainability reports according to GRI standards in Peruvian mining companies supervised by the SMV in 2018: deficiencies and opportunities
}

\begin{abstract}
Uma análise do conteúdo e da qualidade dos relatórios de sustentabilidade de acordo com os padrões da GRI em empresas peruanas de mineração supervisionadas pela SMV em 2018: deficiências e oportunidades
\end{abstract}

Un análisis del contenido y calidad de los reportes de sostenibilidad corporativa según estándares GRI en compañías peruanas mineras supervisadas por la SMV en 2018: deficiencias y oportunidades

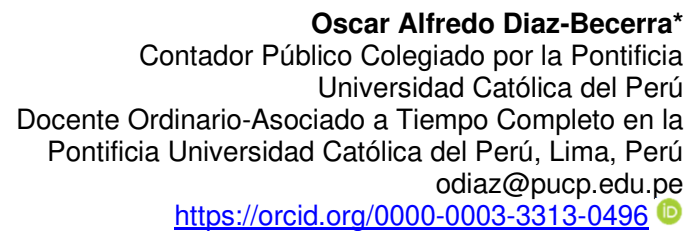

https://orcid.org/0000-0003-3313-0496 (1)

\author{
Claudia Leon-Chavarri \\ Maestro en Ingeniería en Ingeniería Civil y Ambiental en el \\ Massachusetts Institute of Technology \\ Docente a Tiempo Completo en la Universidad Peruana de Ciencias \\ Aplicadas, Lima, Perú \\ claudia.leon@upc.edu.pe \\ https://orcid.org/0000-0002-2919-8351 (1) \\ Brenda Ampuero-Alfaro \\ Contador Público Colegiado por la Pontificia \\ Universidad Católica del Perú \\ Pre-docente en la Pontificia Universidad Católica del Perú, Lima, Perú \\ brenda.ampuero@pucp.edu.pe \\ https://orcid.org/0000-0001-9797-6007
}

Primary contact address for correspondence* Av. Universitaria 1801, San Miguel, CP: 15088, Lima, Perú

\begin{abstract}
Corporate sustainability has become a distinctive factor of global leaders, who communicate sustainable development actions using corporate sustainability reports (CSR) in accordance with international reporting standards such as GRI. In Latin America there is a high variability in their adoption and the Peruvian mining sector has been facing credibility problems due to the incidence of socio-environmental conflicts in its projects, despite its recent consistency in the presentation of CSR. A statistical analysis of a sample of mining companies that submitted their CSR to the SMV in 2018 showed that half of them complied with presenting CSR; nonetheless, GRI principles are not strictly followed. Reports stress the social pillar over the environmental and economic ones; with an imbalance between positive, neutral and negative actions; and do not present their sources to make data auditable. An opportunity is presented for the creation of a specialized area in the SMV to review CSR.
\end{abstract}

Keywords: Corporate sustainability; Sustainability reports; GRI; Latin America

\section{Resumo}

A sustentabilidade corporativa tornou-se um fator distintivo dos líderes globais, que comunicam ações de desenvolvimento sustentável por meio de relatórios de sustentabilidade corporativa (RSC) de acordo com padrões internacionais de relato, como a GRI. Na América Latina existe uma grande variabilidade na sua adoção e o setor de mineração peruano enfrenta problemas de credibilidade pela incidência de conflitos socioambientais em seus projetos, apesar de sua recente consistência na apresentação dos RSC. Uma análise estatística de uma amostra de empresas de mineração que submeteram seu RSC à SMV em 2018 
mostrou que metade delas cumpriu com a apresentação de RSC; mas os princípios GRI não são seguidos à risca. Os relatórios enfatizam o pilar social sobre o ambiental e econômico; com um desequilíbrio entre ações positivas, neutras e negativas; e não apresentam suas fontes para tornar os dados auditáveis. Surge a oportunidade de criar uma área especializada na SMV para revisar RSC.

Palavras-chave: Sustentabilidade corporativa; Relatórios de sustentabilidade; GRI; América Latina

\section{Resumen}

La sostenibilidad corporativa se ha convertido en un factor distintivo de los líderes globales, quienes comunican acciones de desarrollo sostenible usando reportes de sostenibilidad corporativa (RSC) según estándares internacionales de reporte como GRI. En Latino América existe una gran variabilidad en su adopción, y el sector minero peruano enfrenta problemas de credibilidad por la incidencia de conflictos socioambientales en sus proyectos, pese a su reciente consistencia en la presentación de RSC. Un análisis estadístico de una muestra de empresas mineras que enviaron RSC a la SMV en 2018 mostró que la mitad cumplía con presentar RSC; pero no siguen estrictamente principios GRI. Estos reportes enfatizan el pilar social encima del ambiental y económico; con un desbalance entre las acciones positivas, neutrales y negativas; y no presentan sus fuentes para hacer que la data sea auditable. Se presenta una oportunidad para crear un área especializada en la SMV para revisar RSC.

Palabras clave: Sostenibilidad corporativa; Reportes de sostenibilidad; GRI; Latino América

\section{Introduction}

In recent decades, terms such as Corporate Responsibility and Corporate Sustainability have been gaining relevance, as concepts associated with evaluating the true value of an organization. According to Swarnapali \& Luo (2018), the practice of reporting an organization's level of performance in sustainability has become common around the world, something in which Bradford, Earp, Shopwalter \& Williams (2017) agree. According to these authors, communicating the actions taken by organizations in the field of sustainable development is not only a trend or an innovative practice, but an action that makes the operations of corporations transparent and makes them more reliable to their stakeholders, by demonstrating a willingness to take responsibility for the repercussions of their activities and operations. However, it is important to highlight that this willingness to communicate environmental management actions may also be strongly motivated by a nonenvironmental interest: the desire to improve public perception of the performance of a company, as Hummel \& Schlick (2016) postulated by doing reference to the theory of legitimacy, which Tower \& Rusmin (2012) especially relate to high-profile companies in the market.

In the Latin American region, studies such as the one carried out by Alonso-Almeida, Marimon \& Llach (2015), as cited by Sepúlveda, Valero \& Bonilla (2018), suggest that the adoption of mechanisms and standards that make actions in favor of sustainability visible at the corporate level have been adopted unevenly, both between countries and between sectors. While Brazil, Colombia, Argentina and Chile lead the lists as the countries that report the most according to international reporting standards (such as the one by the Global Reporting Initiative, GRI), Peru, which has been highlighted by the International Monetary Fund (IMF) as one of the strongest economies of the region (Ministry of Economy and Finance, 2019), is at an intermediate level of reporting, only above those countries that do not present sustainability reports (Sepúlveda et al, 2018).

In this sense, the present investigation explores the Peruvian situation of corporate sustainability reporting in mining, an extremely important economic activity for Peru, contributing $10 \%$ of its GDP, representing $61 \%$ of the value of its exports (Ministry of Energy and Mining, 2019) and having kept the country's growth afloat, even in adverse world scenarios (World Bank, 2019), but whose dynamic role is frequently clouded in the public domain due to its incidence in almost two thirds of the socio-environmental conflicts that are reported in Peru (Observatory of Mining Conflicts in Peru, 2018). In the same sense, there is evidence of social, environmental and economic events, linked to the activities carried out by the Peruvian mining sector, which in one way or another have an impact on the environment and on the communities linked to these activities, such as the use and conservation of water, pollution by gas emissions and the like, forced labor, absence of services and basic infrastructure, conflicts with communities, among others (Cárdenas \& Saraiva, 2016; Narrea, 2018; De Echave, 2018). This kind of negative relationship between the growth opportunities offered by mining activity and the environmental impacts it generates, demands that studies on the use and quality of corporate sustainability reports in the Peruvian mining industry be deepened.

In particular, the research objective is to analyze the level of compliance with GRI guidelines in the corporate sustainability reports presented by mining companies to the SMV in the 2018 period.

The study focuses on mining companies listed on the SMV, which are required to present a format that summarizes the information normally included in Corporate Sustainability Reports (SMV, 2015), which makes it possible to analyze the reporting capacity of mining organizations on a supervised group made up of 16 companies. A semi-quantitative analysis of the CSRs voluntarily submitted by this group of companies allowed the identification of reporting gaps in relation to the content dimensions and quality principles that the GRI postulates for these reports. In this context, the results of the research will contribute so that those obliged to 
present the CSR, design strategies to raise the quality of the sustainability reports of this important economic sector, considering the requirements of GRI reports and the new regulations approved by the SMV in force from the year 2021.

This work has been structured in five sections: the first section corresponds to the introduction; the second section consists of a review of the literature, to know the terminology and state of development of sustainability reports and reporting standards; the third section proposes a methodology to analyze the reports presented by the Peruvian mining companies taking into account previous works in this field; which enable the presentation of the results of the analysis in section four; and finally the fifth section where the conclusions of the authors are presented.

\section{Literature Review}

\subsection{Corporate Sustainability (CS)}

In 1987, the United Nations World Commission for the Environment coined the term sustainability as "the ability to meet the needs of the present without compromising the ability of future generations to meet their own needs." (World Commission on Environment and Development, 1987). This concept, which was born in the field of environmental management, is taken to the corporate management level, first, in relation to meeting the needs and expectations of stakeholders, and evolves over the years to incorporate an integrated vision of economic, social and environmental aspects in a more reflective perspective of the repercussions of business operations, as condensed in the research by Bradford et al. (2017)

To refer to this search for a balance between the economic, social, and environmental results in a single term, the concept of the "triple bottom line" (TBL) or pillars of sustainability is commonly used. This represents the integration of economic viability, social responsibility, and environmental responsibility. In many cases an environmental approach is carried out, but in the case of sustainability, economic and social aspects are considered for the creation of long-term value (Mohanty, 2018).

According to Fallon (2014, as cited by Tate \& Bals, 2018), businesses achieve this goal and become sustainable by incorporating a variety of sustainability efforts such as energy efficiency, reduced carbon footprint, recycling and reuse, fair employee treatment, and charitable giving. Carter \& Rogers (2008) conclude that this is possible when companies engage in activities that create long-term benefits for their firms while positively impacting the environment and society. Their analysis suggest that companies can achieve sustainability if they actively pursue this strategic objective and are willing to evolve their corporate culture. In turn, this creates competitive advantages and reduce external risks related to boycotts and targeted actions from unsatisfied stakeholders.

In some economic sectors, as is the case of the mining industry, being a sustainable business is a matter of survival. As Böhling, Murguía \& Godfrid (2017) report, mining companies require the approval of a number of actors to ensure the continuity of their operations. Their research points out that risks and adverse impacts that large-scale mining has on the natural environment and the livelihoods of local communities has given rise to a "dirty business" reputation of the mining industry. Maintaining the viability of their business model demands fulfilling social expectations and confronting ingrained prejudices derived from their well-known environmental impacts.

Peruvian mining companies are not exempt of this struggle, and often the search for sustainability involves that corporate management implements actions to replace the absence of the role of the state to supply basic services for the communities around its business activity, since otherwise, such as Schutzer (2012) mentions: "Environmental problems can be aggravated by the lack of plans and related public policies: (i) prevention of pollution; (ii) natural resource planning; (iii) basic sanitation (iv) treatment and elimination of waste; (v) urban planning, (vi) use of drinking water, among others "(Quoted in Silva, Díaz-Becerra \& Lunkes, 2016, p.196).

\subsection{Corporate Sustainability Reports (CSR)}

At the beginning of the 20th century, some questions arose about the damage caused by business activity in nature, aggravated by the absence or reduced contribution to society to remedy the damage caused. It is in this context that the term "accountability" arises and is consolidated, as well as the instrument called "Social Balance", reaching what is now known as the Corporate Sustainability Report (De Almeida \& Bastos, 2016).

With the incorporation of CS into the management of organizations, it became necessary to have a mechanism to publicize the actions taken to achieve sustainable development in its operations. In this sense, CSRs are communication tools that integrate information of interest to stakeholders regarding the financial and non-financial performance of organizations (Kumar \& Das, 2018), which add value to the firms that present them (Swarnapali et al, 2018).

According to a study published by D'Aquila (2018), at the international level, medium and large corporations have been adopting the practice of publishing their CSR, reaching more than 80,000 reports by 
2016. This growth in the reporting culture is especially noteworthy when considering that the presentation of CSRs is mainly voluntary (Horváth ett al., 2017).

However, despite these advances in the adoption of CSR, D'Aquila (2018) also points out that "more work needs to be done to improve the quality of sustainability reports" and quotes Deloitte to make the existence of multiple report standards visible, with differentiated approaches in content and target audience. This concern in the consistency of the reports also coincides with that published by Maroun (2017), who promptly highlights the need to make the information reported in the CSR reliable.

When analyzing studies on Latin America, such as those presented by Alonso-Almeida et al. (2015) as cited by Sepúlveda et al. (2018), it is reasonable to assume that the gaps in the quality of reports are deeper in Latin countries.

\subsection{Global Reporting Initiative (GRI)}

As references of some instrument linked to environmental or sustainability issues, we can identify the International Standardization Organization (ISO) Norms, which address issues of environmental management and corporate social responsibility; the requirements issued by the Institute for Social and Ethical Accountability (ISEA) of Great Britain, related to aspects of corporate social responsibility; the standards issued by the Social Accountability International (SAI), which aimed to demonstrating the practices of social responsibility within an organization; and finally, the Brazilian Institute of Business and Social Responsibility (IERS), whose objective is to provide a support tool for issues related to social responsibility and sustainable development (González, Díaz \& Choy, 2019).

The Global Reporting Initiative (GRI) is a pioneering international organization in the field of CSR. Firstly, by being the first to establish international guidelines for the preparation of sustainability reports and, later, by publishing the first global standard for sustainability reporting (GRI, 2021).

GRI reporting guidelines can be grouped into two types of guidelines: content, which refer to what information should be reported; and quality, which indicates criteria on how such information should be reported. Furthermore, with the presentation of the GRI standards in 2016, a clear structure was defined that must be followed in the CSR. According to GRI (2016), the reporting principles for defining report content are Stakeholder Inclusiveness, Sustainability Context, Materiality and Completeness; while the principles for defining report quality are Accuracy, Balance, Clarity, Comparability, Reliability and Timelines, as summarized in Table 1.

Table 1:

Gri Reporting Principles Definition

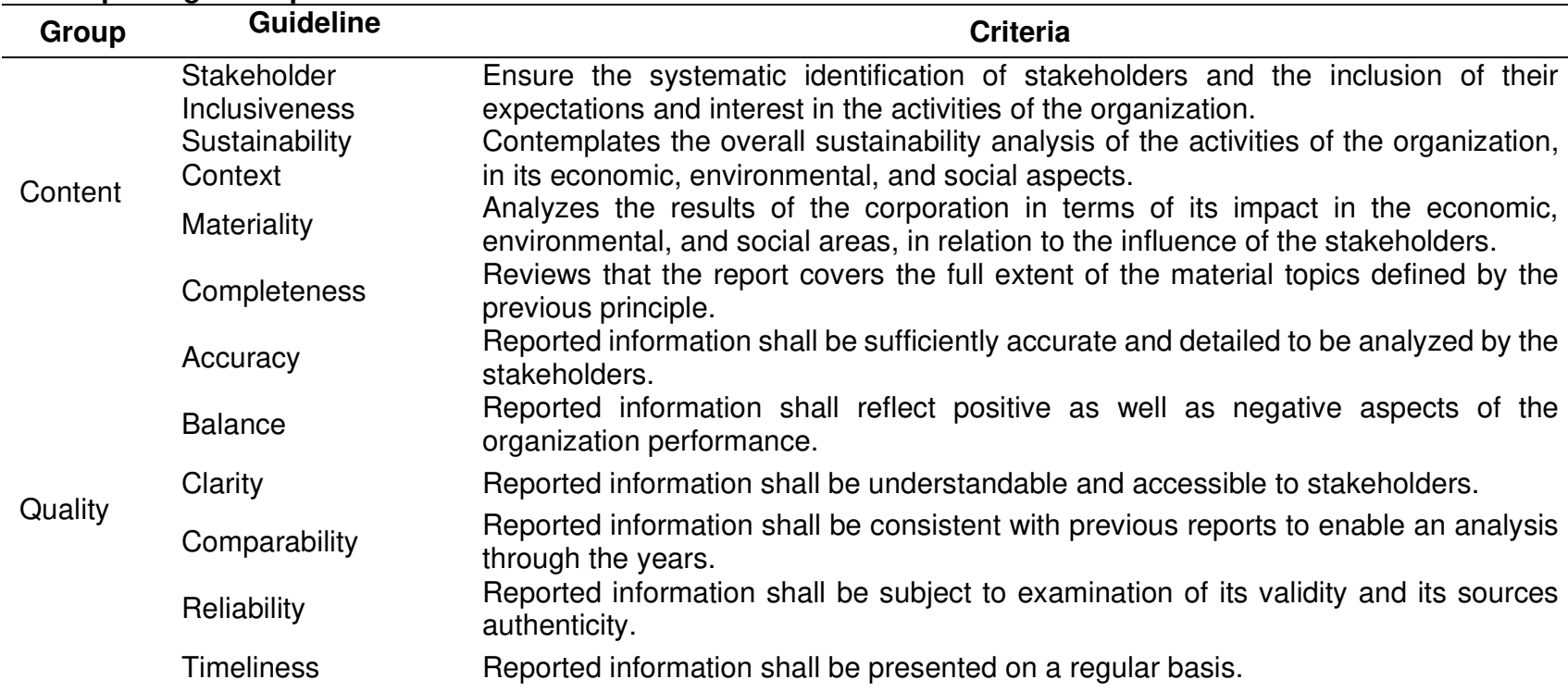

Note: The definition of the reporting criteria for each principle was based upon the GRI 101: Foundation document published by GRI (2016).

According to Yang, Orzes, Jia \& Chen (2019), previous research has managed to demonstrate the predominance of GRI guidelines as a reference standard in the elaboration of CSR worldwide. Multiple publications (Bradford et al., 2017; Gallén \& Peralta, 2018; Maroun, 2017; Uyar, 2017) take the regulatory framework developed by GRI as a point of comparison to measure the development of the reporting culture and the quality of the content of these corporate reports. Therefore, it is important to study its adoption in the Latin American context, specifically in the Peruvian mining reality. 


\subsection{Peruvian Regulation Regarding Sustainability Report}

On December 15, 2015, SMV Resolution No. 033-2015-SMV / 01 was issued, which resolves that the companies supervised by the SMV incorporate an additional annex to section IV of the Report: "Corporate Sustainability Report" (10180). This report has two sections: A. to reveal progress in the implementation of actions to ensure corporate sustainability; $B$. detail the actions implemented during the year. This annex is required from the 2016 period. These annexes are not replaced by the CSR according to GRI that companies have been preparing before the effective date of this standard, they are only intended to present information on the level of compliance and are not alienated from the GRI standards.

According to the information available on the SMV website, a total of 208 companies complied with presenting the CSR in 2016 as required by this institution, while in 2017 a total of 212 companies complied with the presentation, and finally, for the year 2018, the number of companies that met the presentation was 205 (SMV, 2020).

On the other hand, on September 30, 2019, Resolution No. 023-2019-SMV / 01 was issued, and it resolves to authorize the dissemination of the project that would replace the "Corporate Sustainability Report" format of the 2015 Resolution. The proposal was prepared to align with the results of the Diagnosis and the recommendations contained in the Roadmap for the Capital Market, documents prepared with the support of the World Bank and with the support of the Swiss Cooperation (SECO). This project seeks to ensure that the report that must be submitted by companies is in line with new trends and that information users can count on relevant information on the long-term sustainability of companies. As part of the arguments of the SMV, it is not the objective that the CSR that must be submitted to the SMV, can be replaced by the GRI Report that some companies prepare voluntarily.

It is expected that these new requirements will begin to apply for the period 2020, which is reported in the year 2021 and that companies were able to apply it voluntarily since the period 2019.

\section{Methodology}

The present research has a non-experimental design, which is supported by documents and public data, taking into consideration the theoretical framework regarding corporate sustainability, the corresponding legal regulations and the technical definitions for sustainability reporting according to GRI standards. The research was chosen to be descriptive, under a Deductive - Inductive research method, through which it is intended to present general conclusions for particular facts, and at the same time to obtain conclusions originating from particular facts, which will contribute with the development knowledge in this area.

The analysis unit for the study of the first objective is composed of the information provided on corporate sustainability by the 16 Peruvian mining companies supervised by the SMV during the 2010-2018 period, which are presented and codified in Table 2.

Table 2:

Mining Companies Supervised by the Superintendence of the Stock Market 2018 Period

Code Company name

\begin{tabular}{ll}
\hline RSC01 & Compañía de Minas Buenaventura S.A.A. \\
RSC02 & Compañía Minera Poderosa S.A. \\
RSC03 & Compañía Minera San Ignacio de Morococha S.A.A. \\
RSC04 & Compañía Minera Santa Luisa S.A. \\
RSC05 & Fosfatos del Pacífico S.A. \\
RSC06 & Minera Andina de Exploraciones S.A.A. \\
RSC07 & Minsur S.A. \\
RSC08 & Nexa Resources Atacocha S.A.A. \\
RSC09 & Perubar S.A. \\
RSC10 & Sociedad Minera Cerro Verde S.A.A. \\
RSC11 & Sociedad Minera Corona S.A. \\
RSC12 & Sociedad Minera El Brocal S.A.A. \\
RSC13 & Southern Perú Copper Corporation, Sucursal del Perú \\
RSC14 & Volcan Compañía Minera S.A.A. \\
RSC15 & RSC16
\end{tabular}

Note: Even though there are many Peruvian mining companies that prepare their CSR, only those that report to the SMV are mandated to make these reports public 
For the exploration and response to the objectives set out in second and third place, the analysis unit is composed of the Corporate Sustainability Reports of the Peruvian mining companies supervised by the SMV. The sampling applied for this second section of the investigation is a non-probability sampling, resulting in a set of the 8 mining companies supervised by the SMV that submitted Corporate Sustainability Reports in 2018, as described in Table 3.

Table 3:

Mining Companies Supervised By The Superintendence Of The Stock Market That Presented CSR Under GRI Guidelines And Standards Period 2018

\begin{tabular}{ll}
\multicolumn{1}{c}{ Code } & \multicolumn{1}{c}{ Company name } \\
\hline RSC01 & Compañía de Minas Buenaventura S.A.A. \\
RSC02 & Compañía Minera Poderosa S.A. \\
RSC08 & Minsur S.A. \\
RSC09 & Nexa Resources Atacocha S.A.A. \\
RSC10 & Nexa Resources Perú S.A.A. \\
RSC12 & Sociedad Minera Cerro Verde S.A.A. \\
RSC14 & Sociedad Minera El Brocal S.A.A. \\
RSC16 & Volcan Compañía Minera S.A.A. \\
\hline
\end{tabular}

Note: The authors considered in this list companies that indicated having GRI reporting standards.

Afterwards, a content analysis assessment was performed on the CSR of these 8 companies. A content analysis is a process by which the researchers "read the documents several times in order to become immersed in the data" (Rashidfarokhi, Toivonen \& Viitanen, 2017). Through this review, it becomes possible to categorize the reported information to develop a quantitative analysis of the compliance of the reporting content and quality principles, based on qualitative information available on the publicly reported CSR.

Nonetheless, a thorough analysis of content reporting principles such as Stakeholder Inclusiveness, Materiality and Completeness, would require access to internal information from each company that is not of open access. Hence, only one out of the four GRI content reporting principles (Sustainability Context) can be measured using this methodology.

For the content principle of GRI, the activities are coded according to the sustainability pillar that they belong to, as well as the specific topic that it represents in its corresponding sustainability pillar. Regarding the quality analysis criteria, the CSR becomes reviewed as a whole on the compliance per each of the six GRI guidelines.

\section{Results}

This section presents the analysis and interpretation of the results obtained in the research project, after reviewing the contents included in the reports, annual reports and sustainability reports presented by the companies in the sample, for the 2018 period, in accordance with the established objectives.

\subsection{Reporting and Regulatory Level}

When analyzing the level of reporting by mining companies supervised by the SMV during the last decade, taking as a reference the public CSR database available at the SMV, it was detected that the level of CSR reporting took off in the year 2016, when 2015 reports were presented. Although 93.8\% of companies presented their annual reports (MA) by 2015, none of the firms presented their CSR report to this institution. The situation changes significantly in 2016, with the introduction of a regulatory requirement that makes the presentation of CSR mandatory, understood according to the requirements set by the SMV and not the GRI reports: $56.3 \%$ reporting in 2016 , and $62.5 \%$ in 2017 and 2018 . It was thus observed that, to date, in addition, $100 \%$ of corporations presented at least the annual report (MA).

The percentages of the level of presentation of documentation on corporate sustainability have been summarized in Table 4. 
Table 4:

Level Of Presentation Of Corporate Sustainability Reports And Annual Memories Per Year From 2010 To 2018

\begin{tabular}{cccc}
\hline Year & CSR Presented & CSR Presented (\%) & Annual Memories Presented (\%) \\
\hline 2010 & 0 & $0 \%$ & $93.8 \%$ \\
2011 & 0 & $0 \%$ & $93.8 \%$ \\
2012 & 0 & $0 \%$ & $93.8 \%$ \\
2013 & 0 & $0 \%$ & $93.8 \%$ \\
2014 & 0 & $0 \%$ & $93.8 \%$ \\
2015 & 0 & $0 \%$ & $93.8 \%$ \\
2016 & 9 & $56.3 \%$ & $93.8 \%$ \\
2017 & 10 & $62.5 \%$ & $100 \%$ \\
2018 & 10 & $62.5 \%$ & $100 \%$ \\
\hline
\end{tabular}

Note: Annual memories refers to documents that presents a summary of the operations and financial development. They differ from CSR in the way they approach non-economic aspects, treating them in a more generic manner.

\subsection{Reporting Level vs GRI}

An analysis was carried out to identify whether the sustainability reports presented by the mining companies, corresponding to the 2018 period, were done according to the standards established by the GRI, taking into account that each company is bound to declare what standard they used to prepare the report voluntarily. The results, shown in Table 5 , demonstrate that only a half of the mining companies use the GRI standard, and that a worrisome $38 \%$ of these organizations do not report to the SMV.

Table 5:

Standards Used For The Presentation Of Corporate Sustainability Reports In The Year 2018

\begin{tabular}{ccc} 
Standard & Standard Used for the CSR & Standard Used for CSR (\%) \\
\hline GRI & 8 & $50 \%$ \\
SMV Format & 1 & $6 \%$ \\
UN SDG & 1 & $6 \%$ \\
Did not report & 6 & $38 \%$ \\
\hline
\end{tabular}

Note: The SMV CSR reporting Act does not demand the use of any specific standard. The institution does provide a form that all companies must fill out and in addition, companies may also annex their extended CSR. This table shows the standard used in the annex.

\subsection{Compliance with GRI Content Dimensions - Sustainability Context}

After identifying the companies that declared having used GRI as a reporting standard, the content of those CSR was reviewed to assess if the Sustainability Context guideline is being followed. Table 6 summarizes the type of information presented in the reports, corresponding to each of the three sustainability pillars considered by GRI according to the TBL concept: economic, social and environmental.

Table 6:

Assessment Of The Gri Content Principle - Sustainability In The Year 2018

\begin{tabular}{ccccccccc}
\hline \multirow{2}{*}{ Code } & \multicolumn{2}{c}{ Economic } & \multicolumn{2}{c}{ Environmental } & \multicolumn{2}{c}{ Social } & \multicolumn{2}{c}{ Overall } \\
& Activities & $\%$ & Activities & $\%$ & Activities & $\%$ & Total & $\%$ \\
\hline RSC01 & 2 & $3.1 \%$ & 28 & $43.8 \%$ & 34 & $53.1 \%$ & 64 & $100 \%$ \\
RSC02 & 4 & $7.3 \%$ & 26 & $47.3 \%$ & 25 & $45.5 \%$ & 55 & $100 \%$ \\
RSC08 & 2 & $2.5 \%$ & 29 & $36.7 \%$ & 48 & $60.8 \%$ & 79 & $100 \%$ \\
RSC09 & 2 & $4.9 \%$ & 14 & $34.1 \%$ & 25 & $61.0 \%$ & 41 & $100 \%$ \\
RSC10 & 2 & $9.1 \%$ & 7 & $31.8 \%$ & 13 & $59.1 \%$ & 22 & $100 \%$ \\
RSC12 & 2 & $3.5 \%$ & 11 & $19.3 \%$ & 44 & $77.2 \%$ & 57 & $100 \%$ \\
RSC14 & 1 & $1.6 \%$ & 24 & $38.1 \%$ & 38 & $60.3 \%$ & 63 & $100 \%$ \\
RSC16 & 1 & $1.8 \%$ & 18 & $31.6 \%$ & 38 & $66.7 \%$ & 57 & $100 \%$ \\
Total & 16 & $3.7 \%$ & 157 & $35.8 \%$ & 265 & $60.5 \%$ & 438 & $100 \%$ \\
\hline
\end{tabular}

Note: Each individual percentage corresponds to the total number of activities reported per Company. 
The greatest emphasis identified in the reports corresponds to social issues or activities, with a participation of 265 reported activities, which corresponds to $60.50 \%$ of the total activities reported. All the companies, with only one exception, report more than $50 \%$ of their activities in the social realm. The company with the most reported social data stands out, with 44 reported activities of this type, which represents $77.19 \%$ of their total activities. This result may be related to the need to minimize the negative perception that their operating activities have among the related community.

The least frequently reported topics are economic, with only 16 activities included in the reports analyzed, which represents $3.7 \%$ of the total activities reported by all companies.

\subsubsection{Economic Pillar}

With regard to the economic issues reported by the companies in the sustainability reports in 2018, which is the one with the lowest number of frequencies reported in the sample analyzed, these are basically referred to the Economic Value generated by the companies and the Economic Value distributed, in some cases in a general way, and in others with a higher level of detail of the elements that make them up. Table 7 presents the number of activities or subjects declared by each company in this pillar, where only one company reported enough of these types of activities to constitute $25 \%$ of the reported economic activities.

Table 7:

Economic Topics Reported By Company In 2018

\begin{tabular}{ccc}
\hline Business code & Economic value & \% Reported economic issues \\
\hline RSC02 & 4 & $25.0 \%$ \\
RSC01 & 2 & $12.5 \%$ \\
RSC08 & 2 & $12.5 \%$ \\
RSC09 & 2 & $12.5 \%$ \\
RSC10 & 2 & $12.5 \%$ \\
RSC12 & 2 & $12.5 \%$ \\
RSC14 & 1 & $6.25 \%$ \\
RSC16 & 1 & $6.25 \%$ \\
Total & 16 & $100.00 \%$
\end{tabular}

Note: The analysis allowed the authors to identify if the companies presented a similar weight of economic topics on their CSR.

\subsubsection{Environmental Pillar}

With reference to the environmental pillar, the topics reported are varied and include a diversity of activities implemented in each area, related to the environmental performance of each company analyzed and the commitment to minimize the negative impact that their activities may cause on the environment. The activities that are most prominent in this pillar are related to environmental management, water management, waste management, energy management and air management, among others, as can be seen in Table 8.

Table 8:

Environmental Issues Reported By Company In 2018

\begin{tabular}{cccccccccc}
$\begin{array}{c}\text { Business } \\
\text { code }\end{array}$ & Environment & Water & $\begin{array}{c}\text { Solid } \\
\text { waste }\end{array}$ & Energy & Air & $\begin{array}{c}\text { Mine } \\
\text { closure }\end{array}$ & $\begin{array}{c}\text { Gas } \\
\text { emissions }\end{array}$ & Others & Total \\
\hline RSC08 & 2 & 6 & 13 & 4 & 0 & 3 & 0 & 1 & $18.5 \%$ \\
RSC01 & 12 & 6 & 2 & 0 & 3 & 2 & 0 & 3 & $17.8 \%$ \\
RSC02 & 9 & 7 & 1 & 6 & 0 & 1 & 1 & 1 & $16.6 \%$ \\
RSC14 & 2 & 5 & 6 & 6 & 5 & 0 & 0 & 0 & $15.2 \%$ \\
Others & 14 & 11 & 8 & 5 & 4 & 3 & 2 & 3 & $31.9 \%$ \\
Total & 39 & 35 & 30 & 21 & 12 & 9 & 3 & 8 & 157 \\
$\%$ & $24.8 \%$ & $22.3 \%$ & $19.1 \%$ & $13.4 \%$ & $7.6 \%$ & $5.7 \%$ & $1.9 \%$ & $5 \%$ & $100 \%$ \\
\hline
\end{tabular}

Note: The analysis shows both the relevance of the Environmental topic to each company, as well as the importance per Environmental aspects overall in these companies. 
In the analysis of the information presented, it was observed that just half of the companies concentrated activities related to environmental issues, representing $68.15 \%$ of the total activities developed by the companies in the sample in the year 2018.

In the case of environmental management, one of the issues with the greatest presence in the environmental pillar, the activities implemented by the companies in the sample are mainly linked to environmental impact studies of their different mining exploration projects, as well as afforestation projects in the different impact areas of their operations.

Likewise, with regard to water management, the second most relevant topic in the pillar, the main activities developed by the companies analyzed correspond to actions to recirculate water, participatory monitoring of water use and consumption, planning to reduce water consumption in operations and in the populations of the areas linked to the operations, among other important actions. In this area, almost all the companies analyzed have a significant share in the total number of activities carried out.

A third important issue is that of waste management, in which the main initiatives implemented by the companies are policies and practices for classifying, separating and recycling solid waste, temporary warehouses for solid waste, and a plan to raise awareness among company personnel and members of the related communities regarding the generation and proper disposal of the solid waste generated.

\subsubsection{Social Pillar}

With regard to the third pillar, the main social issues reported in the period 2018 by the companies analyzed, correspond to social investment, work environment, and occupational health and safety (OHS), with other topics conforming only $14 \%$ of the data reported, as can be seen in Table 9 . In this pillar, it is observed that all the companies in the sample analyzed have developed a number of important actions; however, similarly to the environmental pillar analysis, most of the reports are concentrated in half of the companies, which have $63.7 \%$ of the social issues present on 2018 CSR.

Table 9:

Social Issues Reported By Company In 2018

\begin{tabular}{|c|c|c|c|c|c|c|c|c|}
\hline $\begin{array}{l}\text { Business } \\
\text { code }\end{array}$ & $\begin{array}{c}\text { Social } \\
\text { investment }\end{array}$ & $\begin{array}{c}\text { Work } \\
\text { environment }\end{array}$ & OHS & Training & Economy & Infrastructure & Communications & Total \\
\hline RSC08 & 32 & 5 & 11 & 0 & 0 & 0 & 0 & $18.1 \%$ \\
\hline RSC12 & 40 & 3 & 1 & 0 & 0 & 0 & 0 & $16.6 \%$ \\
\hline RSC14 & 30 & 9 & 0 & 0 & 0 & 0 & 0 & $14.7 \%$ \\
\hline RSC16 & 14 & 15 & 5 & 0 & 4 & 0 & 0 & $14.3 \%$ \\
\hline Others & 16 & 10 & 23 & 15 & 7 & 7 & 4 & $36.3 \%$ \\
\hline Total & 146 & 42 & 40 & 15 & 11 & 7 & 4 & 265 \\
\hline$\%$ & $55.1 \%$ & $15.8 \%$ & $15.1 \%$ & $5.7 \%$ & $4.2 \%$ & $2.6 \%$ & $1.5 \%$ & $100 \%$ \\
\hline
\end{tabular}

Note: The analysis shows both the relevance of the Social topic to each company, as well as the importance per Social factors overall in these companies.

Regarding the issue of social investment, which is the one with the highest participation in this standard, with $55.1 \%$ and a total of 146 activities reported, the most common and important initiatives or actions carried out by the companies in the sample analyzed are: training activities on health and safety issues, among others, for the inhabitants of the related areas; individual participation or shared collaboration with government institutions, to improve schools, hospitals, roads and similar; various training and support programs for sustainable ventures or businesses; scholarship programs for studies and training at different educational levels, as support for members of the communities where their operations may have some kind of impact. It is interesting to highlight how just three of these companies account for $69.86 \%$ of the reports in this area.

The second most important issue, due to the number of activities developed, is the Work Environment, with 42 initiatives implemented, achieving a participation of 15.8\%, where two companies stand out, with 15 and 9 activities developed. In this area, activities such as recruitment and talent retention programs; economic support linked to work performance; implementation of surveys and work climate indicators; programs to combat discrimination, forced labor and hiring of minors, among other activities, stand out.

The third most important issue is OHS, with 40 initiatives implemented it has a participation of $15.1 \%$ of the total activities of the pillar. The companies that report the highest participation in this area, contribute with 14 and 11 activities. There are also two companies that do not report any activities or initiatives in relation to this issue, despite OHS management being mandatory in the Peruvian territory. The main and most frequent initiatives in this area are programs aimed at preventing accidents and minimizing the occurrence and severity of accidents; training for employees, contractors and third parties on procedures for preventing occupational accidents; preventive health and awareness campaigns, among other similar activities. 


\subsection{Compliance with GRI Quality Principles}

The final step to assess if a CSR actually meets GRI standards is to analyze whether they comply with the six GRI guidelines. This study found that the balance and reliability criteria are not properly followed, as Table 10 summarizes.

TABLE 10:

COMPLIANCE WITH GRI QUALITY PRINCIPLES IN THE YEAR 2018

\begin{tabular}{|c|c|c|c|c|c|c|}
\hline Code & Balance & Comparability & Accuracy & Periodicity & Clarity & Reliability \\
\hline RSC01 & $\begin{array}{l}69 \% \text { of reported } \\
\text { actions are }(+)\end{array}$ & YES & YES & YES & YES & NO \\
\hline RSC02 & $\begin{array}{l}88 \% \text { of reported } \\
\text { actions are }(+)\end{array}$ & YES & YES & YES & YES & NO \\
\hline RSC08 & $\begin{array}{c}70 \% \text { of reported } \\
\text { actions are }(+)\end{array}$ & YES & YES & YES & YES & NO \\
\hline RSC09 & $\begin{array}{l}93 \% \text { of reported } \\
\text { actions are }(+)\end{array}$ & YES & YES & YES & YES & NO \\
\hline RSC10 & $\begin{array}{l}73 \% \text { of reported } \\
\text { actions are }(+)\end{array}$ & YES & YES & YES & YES & NO \\
\hline $\mathrm{RSC} 12$ & $\begin{array}{c}72 \% \text { of reported } \\
\text { actions are }(0)\end{array}$ & YES & YES & YES & YES & YES \\
\hline RSC14 & $\begin{array}{c}53 \% \text { of reported } \\
\text { actions are }(+)\end{array}$ & YES & YES & YES & YES & NO \\
\hline $\mathrm{RSC} 16$ & $\begin{array}{l}\text { 78\% of reported } \\
\text { actions are }(+)\end{array}$ & YES & YES & YES & YES & NO \\
\hline
\end{tabular}

Note: For the balance dimension, the authors use (+) for positive actions, (-) for negative actions and (0) for neutrals. Also, in regards of periodicity, the authors assessed consistency in the reports throughout three consecutive years.

\subsubsection{Balance}

For the companies in the sample, the number of sustainability actions affecting the following issues was analyzed: Environment, Decent Work, Economic, Social, Human Rights, Product Responsibility and Risk and Compliance. After the segregation of the shares, they were given a rating: negative if they represent shares that could affect in a manner contrary to mining, neutral if the share is not related to the operations of the corporation, and positive if the share is for the improvement of the operation (see Table 11).

Table 11:

Assessment Of The Gri Quality Principle - Balance In The Year 2018

\begin{tabular}{ccccccccc}
\hline \multirow{2}{*}{ Code } & \multicolumn{2}{c}{ Positive } & \multicolumn{2}{c}{ Neutral } & \multicolumn{2}{c}{ Negative } & \multicolumn{2}{c}{ Most reported } \\
& Activities & $\%$ & Activities & $\%$ & Activities & $\%$ & Max & $\%$ \\
\hline RSC01 & 44 & $68.8 \%$ & 20 & $31.3 \%$ & 0 & $0 \%$ & $68.8 \%$ & Positive \\
RSC02 & 48 & $87.3 \%$ & 7 & $12.7 \%$ & 0 & $0 \%$ & $87.3 \%$ & Positive \\
RSC08 & 55 & $69.6 \%$ & 24 & $30.4 \%$ & 0 & $0 \%$ & $69.6 \%$ & Positive \\
RSC09 & 38 & $92.7 \%$ & 3 & $7.3 \%$ & 0 & $0 \%$ & $92.7 \%$ & Positive \\
RSC10 & 16 & $72.7 \%$ & 6 & $27.3 \%$ & 0 & $0 \%$ & $72.7 \%$ & Positive \\
RSC12 & 16 & $28.1 \%$ & 41 & $71.9 \%$ & 0 & $0 \%$ & $71.9 \%$ & Neutral \\
RSC14 & 33 & $52.4 \%$ & 30 & $47.6 \%$ & 0 & $0 \%$ & $52.4 \%$ & Positive \\
RSC16 & 44 & $77.2 \%$ & 13 & $22.8 \%$ & 0 & $0 \%$ & $77.2 \%$ & Positive \\
\hline
\end{tabular}

Note: The reported activities were categorized as positive, neutral or negative and the frequency of each category was counted. This became a tool to quantify and verify the compliance with the balance principle.

The assessment showed that none of the companies report negative issues that may have impacted the operations or that have been identified and remain unresolved. Taking into account the socio-environmental conflicts officially reported in the country linked to mining projects, this finding shows a gap in the ability or willingness of the companies to comply with the balance principle and show transparency on the issues presented in their reports.

Another interesting finding was that some companies report sustainability activities that qualify with a "neutral" rating. This means that the activity could be linked to philanthropic activity and not related to the operations of the company, therefore not related to the capacity of the companies to create long term value. 
At the other extreme are companies that report a small percentage of activities with neutral valuations and show a majority of activities that correspond to positive evaluations. This implies that their activities are linked to the operation of the mine and the improvement of whatever affects it.

\subsubsection{Comparability}

When analyzing the documents under this guideline, no differences were found between the period under study and the previous period in relation to the standard taken as reference. The mining companies supervised by the SMV, considered in the sample, presented reports under GRI guidelines in a consistent manner, which makes it possible to compare the information presented between one reporting period and another. It should be noted that the reports submitted constitute additional documentation to the format required by the SMV regulations, which shows the interest of these entities in making their activities transparent and showing themselves to be responsible for the repercussions of their operations in economic, social and environmental matters.

\subsubsection{Accuracy}

The quantitative information presented by each company within the CSR was evaluated and all have included data accompanying their actions to be able to specify their impact. Therefore, no difference or noncompliance was found either.

\subsubsection{Timeliness}

When analyzing the information since 2010, it was observed that all the companies in the sample submitted their information to the SMV since 2016 on a constant basis. This is in line with the regulatory requirement that was presented in the Literature Review. Even so, it is important to mention that the companies in the sample present their CSRs on their websites from years prior to 2016, so that interested parties can have the information available for their decision-making.

\subsubsection{Clarity}

Analyzing the CSR of the companies in the sample, it was found that the wording is understandable, and all the companies would be complying with this guideline.

\subsubsection{Reliability}

Finally, while we comment that the CSRs of the companies in the sample comply with presenting accurate quantitative information, none of the companies comply with the reliability guideline. This is because there is no indication of a source from which the information presented is obtained. So, in the event of an audit, the figures could be questioned.

\section{Discussion}

The non-financial information of this group of companies reflects the intention to present, mainly, actions implemented in relation to aspects related to the social impacts with the surrounding communities where they carry out their productive activity, which may be related to compliance with the formal part of presenting the reports due to a legal requirement and an intention to improve its image in contrast to its high incidence in socioenvironmental conflicts. Although they comply with local regulations, the positive actions that have been implemented in the analyzed period are highlighted with greater emphasis, which may affect the transparency of the information, as is intended when applying the principle of balance in the reports on the GRI standards base.

An interesting fact is also that some of these positive actions are not related to the know-how and continuity of the core business of these organizations, losing the opportunity to generate value associated with mining activity. It is also worth noting that, even though CSR under GRI is intended to be auditable, a high proportion of the reports submitted to the SMV lacked references that could allow to confirm or verify the veracity of the qualitative and quantitative information presented.

Greater analysis and supervision of the information is required for companies to comply with the established requirements, so there should be a specialized area in the SMV responsible for reviewing that the information presented complies with reporting best practices and standards.

\section{Conclusions}

The analysis of the results showed that out of the 16 mining companies supervised by the SMV, only 8 
have voluntarily submitted the Corporate Sustainability Reports in accordance with the GRI standards. The other companies only present the format required by the SMV in its 2015 Resolution. Although this annex constitutes an important initiative to require supervised companies to report on CSR, it is limited and represents a contrast to the global trend that medians and large corporations present their CSR. Based on the effect of the 2015 regulation, it is expected that the new SMV project, which would come into effect from the 2020 period onwards, could improve the information presented by the companies supervised by this institution, but it would still have differences with the guidelines used globally, since as indicated in the project documents, no other report, including the GRI report, can replace the CSR required by the SMV. Improving local regulations should tend to require the presentation of CSRs in accordance with international standards, regardless of the standardized compliance information requested by the supervisor.

Further analysis on the companies in the sample which reported that they submitted their CSR under GRI standards allows us to conclude that there is a deficiency in the sustainability guideline within the content principle that calls companies to report information of the three pillars of the TBL. Most of the 8 companies' reports present information focused on social activities and to a lesser extent they focus on environmental and economic activities. According to the individual analysis of the activities carried out by each company, this emphasis may be related to the objective of addressing the discontent of the communities involved, regarding the impact of business operations and calming political turmoil, instead of constituting related actions to comply with international standards. Further research is necessary to determine the incentives that move companies to primarily report social activities that are not related to their core-business processes, and which are the real and objective benefits that they get from such actions. Moreover, the next step could be the design of a management instrument to help align their social efforts to the companies' know-how, to create short- and long-term value.

Also, when reviewing the quality of the information presented according to the GRI guidelines, deficiencies were observed with respect to the Balance and Reliability guidelines. On the balance side, the companies analyzed do not present negative issues that may be affecting them and try to compensate them with neutral and some positive issues. This is because the political and social upheaval leads companies to try to calm down the compromised population. Thus, companies fail to carry out activities directly for the purpose of the organization. In addition, these companies also fail to ensure the reliability of the information, which can lead to questions about what is reported, if an evaluation of the sources is required. In this sense, it is recommended that organizations ensure that they present audited information, as the GRI guideline itself recommends, and include mechanisms that promote the transparency of relevant information for stakeholders.

Future research should focus on developing tools to avoid the deficiencies previously mentioned. Concerning the lack of balance in the reports, an integrated management model could be designed to encourage finding the neutral and negative activities, as an input for the continuous improvement of the organization. And in regards of the reliability issues, new studies could aim to develop reporting mechanisms to facilitate companies the presentation of auditable information.

In addition, this research methodology sets a precedent to carry out similar exploratory analysis in other Peruvian industries, to close the gap in regards of the assessment of CSR adoption and GRI compliance. Such information would present an opportunity to provide standardized non-financial information to stakeholders, to allow Peru to improve the reporting level and be align with the leading Latin American countries, such as Brasil, Colombia, Argentina, and Chile.

\section{References}

Bradford, M., Earp, J. B., Showalter, D. S., \& Williams, P. F. (2017). Corporate sustainability reporting and stakeholder concerns: Is there a disconnect? Accounting Horizons, 31(1), 83-102.

https://doi.org/10.2308/acch-51639

Böhling, K., Murguía, D. I., \& Godfrid, J. (2019). Sustainability Reporting in the Mining Sector: Exploring Its Symbolic Nature. Business and Society, 58(1), 191-225. https://doi.org/10.1177/0007650317703658

Cárdenas, M. J., \& Saraiva, M. (2016). Vulnerabilidad social y la minería en el Perú: un análisis comparativo. Revista de Ciencia Política y Gobierno, 3(6), 231-249. https://doi.org/10.18800/rcpg.201602.010

Carter, C. R., \& Rogers, D. S. (2008). A framework of sustainable supply chain management: Moving toward new theory. International Journal of Physical Distribution and Logistics Management, 38(5), 360-387. https://doi.org/10.1108/09600030810882816

D'Aquila, Jill M. (2018). The Current State of Sustainability Reporting: A work in progress. CPA Journal. New York, 44-50.

De Almeida, F., \& Bastos, N. (2016). Experiências Corporativas. Pesquisa em Governança e Sustentabilidade. Livrus Negócios Editoriais, São Paulo. 
An analysis of the content and quality of corporate sustainability reports according to GRI standards in Peruvian mining companies supervised by the SMV in 2018: deficiencies and opportunities

De Echave Caceres, J. (2018). Diez años de minería en el Perú (2008-2017).

http://cooperaccion.org.pe/publicaciones/diez-anos-de-mineria-en-el-peru-2008-2017/

Gallén, M. L., \& Peraita, C. (2018). The effects of national culture on corporate social responsibility disclosure: a cross-country comparison. Applied Economics, 50(27), 2967-2979.

https://doi.org/10.1080/00036846.2017.1412082

González, J., Díaz, O., \& Choy, E. (2019). Retos y propuestas de la profesión contable para el desarrollo de economías sustentables en Latinoamérica. Quipukamayoc, 27(54), 73-81.

Global Reporting Initiative. (2016). GRI 101: Foundation 2016 101. GRI Standards, GRI101(1), 29. www.globalreporting.org

Global Reporting Initiative. (2021, January 28). GRl's History. https://www.globalreporting.org/aboutgri/mission-history/

Horváth, P., Pütter, J. M., Dagilienè, L., Dimante, D., Haldma, T., Kochalski, C., Král, B., Labaš, D., Lääts, K., Bedenik, N. O., Pakšiová, R., Petera, P., Ratajczak, P., Buhovac, A. R., Sava, A., Sucală, V. I., Tirnitz, T. J., \& Wagner, J. (2017). Status quo and future development of sustainability reporting in central and eastern Europe. Journal of East European Management Studies, 22(2), 221-243. https://doi.org/10.5771/0949-61812017-2-221

Hummel, K., \& Schlick, C. (2016). The relationship between sustainability performance and sustainability disclosure - Reconciling voluntary disclosure theory and legitimacy theory. Journal of Accounting and Public Policy, 35(5), 455-476. https://doi.org/10.1016/i.jaccpubpol.2016.06.001

Kumar, A., \& Das, N. (2018). Sustainability reporting practices in emerging economies: A cross-country study of BRICS nations. Problemy Ekorozwoju, 13(2), 17-26.

Maroun, W. (2018). A Conceptual Model for Understanding Corporate Social Responsibility Assurance Practice. Journal of Business Ethics, 1-23. https://doi.org/10.1007/s10551-018-3909-z

Ministry of Economy and Finance (2019). FMI califica a economía peruana entre las más fuertes de la región. Retrieved January 09, 2020, from

https://www.mef.gob.pe/es/component/content/article?id=3170\%\&ltemi-=

Ministry of Energy and Mining (2019): Casi el 10\% del PBI y el 61\% de las exportaciones del 2018 fueron producto de la minería | Gobierno del Perú. (n.d.). Retrieved January 08, 2020, from https://www.gob.pe/institucion/minem/noticias/29754-minem-casi-el-10-del-pbi-y-el-61-de-las-exportacionesdel-2018-fueron-producto-de-la-mineria

Mohanty, L. (2018). Sustainability Accounting and Reporting Practices in India. Srusti Management Review, 11(1), 39-46.

https://search.proquest.com/docview/2201630225?accountid=14338\%0Ahttps://tilburguniversity.on.worldcat. org/atoztitles/link? genre $=$ article\&issn $=09744274 \&$ title $=$ Srusti + Management+Review\&volume $=11 \&$ issue $=1 \& d$ ate $=$ Jan-Jun+2018\&atitle $=$ SUSTAINABILIT + Y + ACCOUNTING + AND $+R$

Narrea, O. (2018). La minería como motor de desarrollo económico para el cumplimiento de los Objetivos de Desarrollo Sostenible 8, 9, 12 y 17. Agenda 2030, 68.

Observatory of Mining Conflicts in Peru (2018). $23^{\circ}$ Observatorio de conflictos mineros en el Perú Reporte Segundo Semestre 2018, 6.

Rashidfarokhi, A., Toivonen, S., \& Viitanen, K. (2018). Sustainability reporting in the nordic real estate companies: Empirical evidence from Finland. International Journal of Strategic Property Management, 22(1), 51-63. https://doi.org/10.3846/ijspm.2018.321

Sepúlveda Alzate, Y. M., Valero Zapata, G. M., \& Bonilla Gómez, M. J. (2018). Un análisis de los estudios acerca de las memorias de sostenibilidad en Latinoamérica. Contabilidad y Negocios, 13(26), 56-73. https://doi.org/10.18800/contabilidad.201802.004 
Silva, F., Díaz-Becerra, O., \& Lunkes, R. (2016). Saneamento básico: Análise da relação entre gastos públicos e atendimento à população em cidades brasileiras e peruanas. Revista Científica General José María Córdova, 14(18), 263-282.

SMV -- Superintendencia del Mercado de Valores. Resolución SMV №33-2015-SMV/01 (2015). https://www.smv.gob.pe/sil/RGG0211199800000007.pdf

SMV -- Superintendencia del Mercado de Valores -- SIL. (n.d.). Retrieved January 09, 2020, from https://www.smv.gob.pe/Frm SIL Detalle.aspx?CNORMA=RSMV00001500033 \&CTEXTO=

Swarnapali, R., \& Le, L. (2018). Corporate sustainability reporting and firm value: Evidence from a developing country. International Journal of Organizational Innovation, 10(4), 69-78.

Tate, W. L., \& Bals, L. (2018). Achieving Shared Triple Bottom Line (TBL) Value Creation: Toward a Social Resource-Based View (SRBV) of the Firm. Journal of Business Ethics, 152(3), 803-826. https://doi.org/10.1007/s10551-016-3344-y

Tower, G. G., \& Rusmin, R. (2012). Legitimising Corporate Sustainability Reporting Throughout the World. Australasian Accounting Business \& Finance Journal, 6(2), 19-34.

Uyar, A. (2017). Stand-Alone Sustainability Reporting Practices in an Emerging Market. The Journal of Corporate Accounting \& Finance, 11-15. https://doi.org/10.1002/jcaf

World Bank (2019), Perú Panorama general. (n.d.). Retrieved January 07, 2020, from https://www.bancomundial.org/es/country/peru/overview

World Commission on Environment and Development. (1987). Chapter 2 : Towards Sustainable Development I . The Concept of Sustainable Development. Our Common Future, 1-19.

Yang, Y., Orzes, G., Jia, F., \& Chen, L. (2019). Does GRI Sustainability Reporting Pay Off? An Empirical Investigation of Publicly Listed Firms in China. Business and Society.

https://doi.org/10.1177/00076503198316329.

\section{NOTES}

\section{ACKNOWLEDGMENT}

Does not apply.

\section{AUTHORSHIP CONTRIBUTION}

Conception and elaboration of the manuscript: O. A. Diaz-Becerra, C. Leon-Chavarri, B. Ampuero-Alfaro Data collection: O. A. Diaz-Becerra, C. Leon-Chavarri, B. Ampuero-Alfaro

Data analysis: O. A. Diaz-Becerra, C. Leon-Chavarri, B. Ampuero-Alfaro

Discussion of results: O. A. Diaz-Becerra, C. Leon-Chavarri, B. Ampuero-Alfaro

Revisão e aprovação: O. A. Diaz-Becerra, C. Leon-Chavarri, B. Ampuero-Alfaro

\section{DATASET}

The entire data set that supports the results of this study was published in the article itself.

\section{FINANCING}

Does not apply.

\section{CONSENT TO USE IMAGE}

Does not apply.

\section{APPROVAL OF THE RESEARCH ETHICS COMMITTEE}

Does not apply.

\section{CONFLICT OF INTERESTS}

Does not apply.

\section{USE LICENSE}

Copyrights for articles published in this journal are the author's, with first publication rights for the journal. Due to appearing in this Public Access Magazine, the articles are free to use, with their own attributions, in 
educational, professional and public management applications. The magazine adopted the Creative Commons Attribution 4.0 International license - CC BY NC ND. This license allows accessing, downloading (downloading), copying, printing, sharing, reusing and distributing the articles provided that the source is acknowledged, attributing the due authorship credits. In such cases, no permission is required from the authors or editors. Authors are authorized to assume additional contracts separately, for non-exclusive distribution of the version of the work published in this journal (eg, publishing in institutional repository or a book chapter).

\section{PUBLISHER}

Federal University of Santa Catarina. Accounting Sciences Course and Postgraduate Program in Accounting. Publication on the UFSC Journal Portal. The ideas expressed in this article are the responsibility of their authors, and do not necessarily represent the opinion of the editors or the university.

\section{EDITORS}

Carlos Eduardo Facin Lavarda and Suliani Rover

\section{HISTORIC}

Received on: 24/09/2020 - Peer reviewed on: 29/12/2020 - Reformulated on: 29/01/2020 - Recommended for publication on: 09/02/2021 - Published on: 22/03/2021 